\title{
Turbulent lifestyle: Microbial mats on Earth's sandy beaches-Today and 3 billion years ago
}

Nora Noffke, Old Dominion University, Department of Ocean, Earth \& Atmospheric Sciences, Norfolk, Virginia 23529, USA

\begin{abstract}
Archean Earth history is very difficult to reconstruct. Until recently, only bacterial cells preserved in chert, microborings, and stromatolites provided the few clues to ancient life. Now, siliciclastic "microbially induced sedimentary structures" (MISS) are adding to our knowledge of both past life and paleoenvironments. MISS rise from the interaction of photoautotrophic microbial mats with physical sediment dynamics in siliciclastic, shallow-marine settings. Archean MISS can be understood through observations of living microbial mats and modern biotic-physical sedimentary processes. Such geobiological studies are key to the interpretation of the early evolution of prokaryotes. For example, the 2.9 Ga Pongola Supergroup, South Africa, includes MISS that possibly point to the oldest known cyanobacterial community preserved in Earth's history.
\end{abstract}

\section{INTRODUCTION}

The question of where and when the earliest life developed on Earth is a most exciting one but also one that is difficult to answer. Time, tectonism, metamorphism, eons of subsurface microbial activity, and unfamiliar biogeochemical environments make the biota of the Archean notoriously difficult to interpret (Lowe and Tice, 2007). Geobiologists approach this problem by combining studies on living biota in modern settings with historical-geological studies on ancient bacteria and biogenic sedimentary structures preserved in Archean rocks. This paper examines "microbially induced sedimentary structures" (MISS) - traces and trace fossils caused by benthic microbial mats in siliciclastic coastal deposits today and 3 billion years ago.

Only a few Archean (3.8-2.5 Ga) fossils and sedimentary structures allow a glimpse into Earth's oldest history. In carbonates and cherts, fossils of bacterial cells and the reef-forming stromatolites record the $3.5 \mathrm{Ga}$ existence of prokaryotes (e.g., Buick, 1992; Hofmann et al., 1999; Grotzinger and Knoll, 1999; Allwood et al., 2007; Schopf et al., 2007). Tube-like fossils finely distributed in Archean seafloor basalts document the fact that living organisms even explored the upper portions of the oceanic crust (Furnes et al., 2004). Laboratory analyses reveal biomolecules in 2.7 Ga black shales in Australia (e.g., Brocks et al., 1999; Knoll, 1999), and various isotopes signal evidence of ancient life even in highly metamorphosed material such as the Isua Greenstone Belt, Greenland (e.g., Grassineau et al., 2006). However, siliciclastic deposits also bear paleontological information: trace fossils caused originally by benthic microbiota.
In the 1980s-1990s, it was suggested that crinkled upper bedding planes ("elephant skin textures") might record ancient microbial mats (e.g., Runnegar and Fedonkin, 1992; Gehling, 1999). Similar conclusions were reached by Seilacher et al. (1985) in lagoonal sediments of Solnhofen, Germany, and by Schieber (1998) in Mesoproterozoic shales of Montana, USA. Those early observations on microbial mat-related structures were summarized in Hagadorn et al. (1999), followed by a photo atlas (Schieber et al., 2007). At about the same time, the genesis of modern microbial mat-associated sedimentary structures was being elucidated (e.g., Cameron et al., 1985; Gerdes and Krumbein, 1987; Gerdes et al., 1991, 1994). The term "microbially induced sedimentary structures" (MISS) was coined in 1996, based on quantitative analyses of mat-related structures in sandy tidal flats (Noffke et al., 1996). The sixteen main types of MISS arise exclusively from the interaction of biofilms and microbial mats with the physical sediment dynamics (Noffke, 2009). This contrasts with the formation of stromatolites, in which chemical precipitation plays a major role. Because of their unique biotic-physical genesis, MISS differ significantly in morphology from stromatolites (Fig. 1).

Systematic studies, leading from modern to increasingly older deposits, have revealed that fossil MISS occur in tidal flat and shelf sandstones of Phanerozoic, Proterozoic, and Archean ages and appear not to have changed identifiably since at least 3.2 Ga (Noffke, 2000; Noffke et al., 2001, 2002, 2003, 2006, 2008). The morphologies and paleoenvironmental distribution of the structures record the former presence of photoautotrophic microbial mats.

Figure 1. Examples for microbially induced sedimentary structures (MISS) from modern sandy tidal flats (A, C, E, G) and from the fossil tidal sandstones of the 2.9 Ga Pongola Supergroup, South Africa (B, D, F, H). (A) Polygonal pattern of oscillation cracks, coast of Tunisia; scale: $12 \mathrm{~cm}$. (B) Fossil oscillation cracks; scale: $8 \mathrm{~cm}$. Arrows indicate margins of polygons. (C) Multidirectional ripple marks, Mellum Island, North Sea; scale: $40 \mathrm{~cm}$. Two storm events are recorded (I, II). (D) Fossil example recording four storm events (I-IV); scale: $40 \mathrm{~cm}$. (E) Erosional remnants (r) and pockets (p), Mellum Island, North Sea; scale: $50 \mathrm{~cm}$. (F) Fossil example; scale: $100 \mathrm{~cm}$. (G) Microbial mat chips, Fishermans Island, Virginia, USA; scale: $5 \mathrm{~mm}$. (H) Fossil mat chips; scale: $5 \mathrm{~mm}$. 

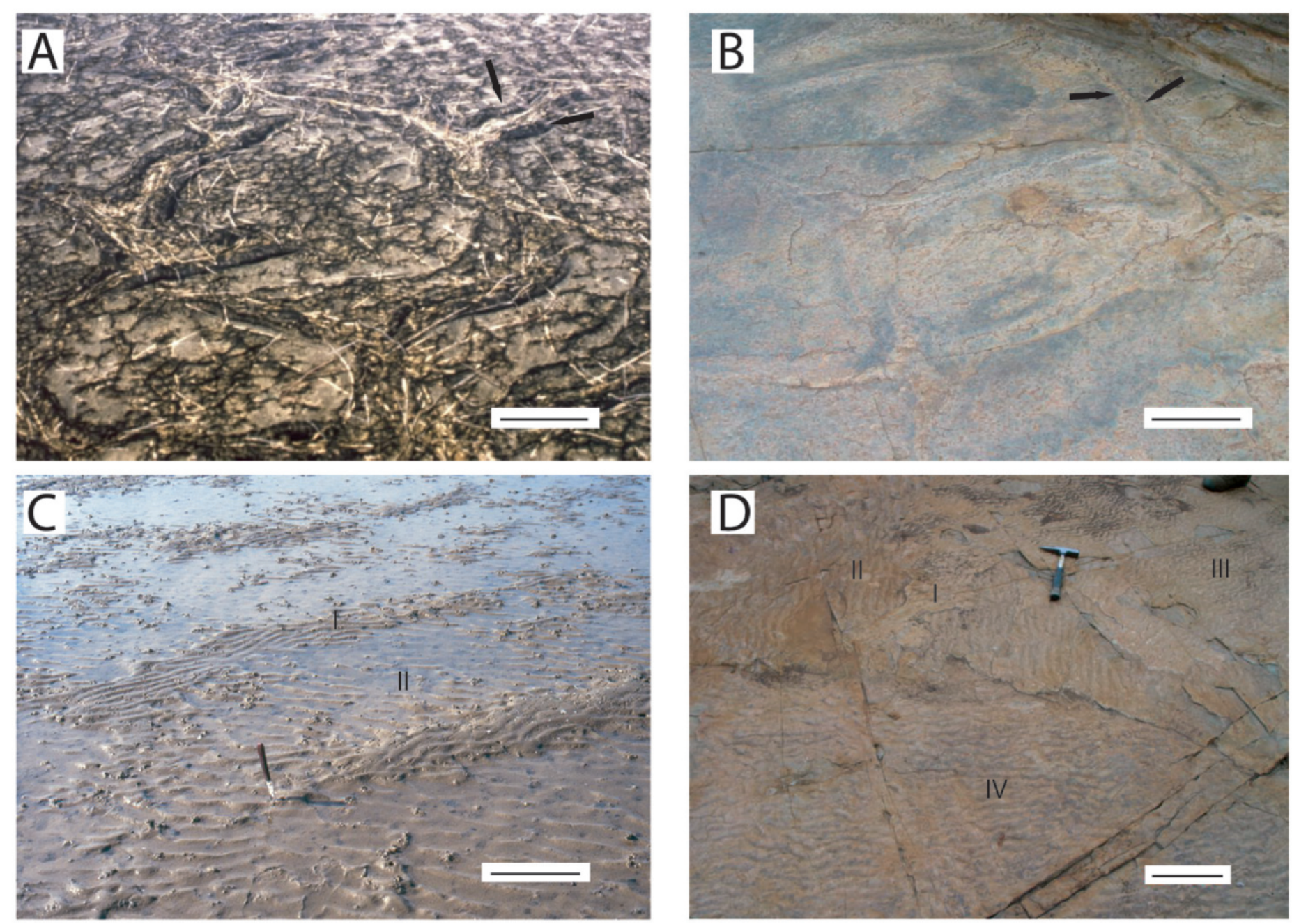

E
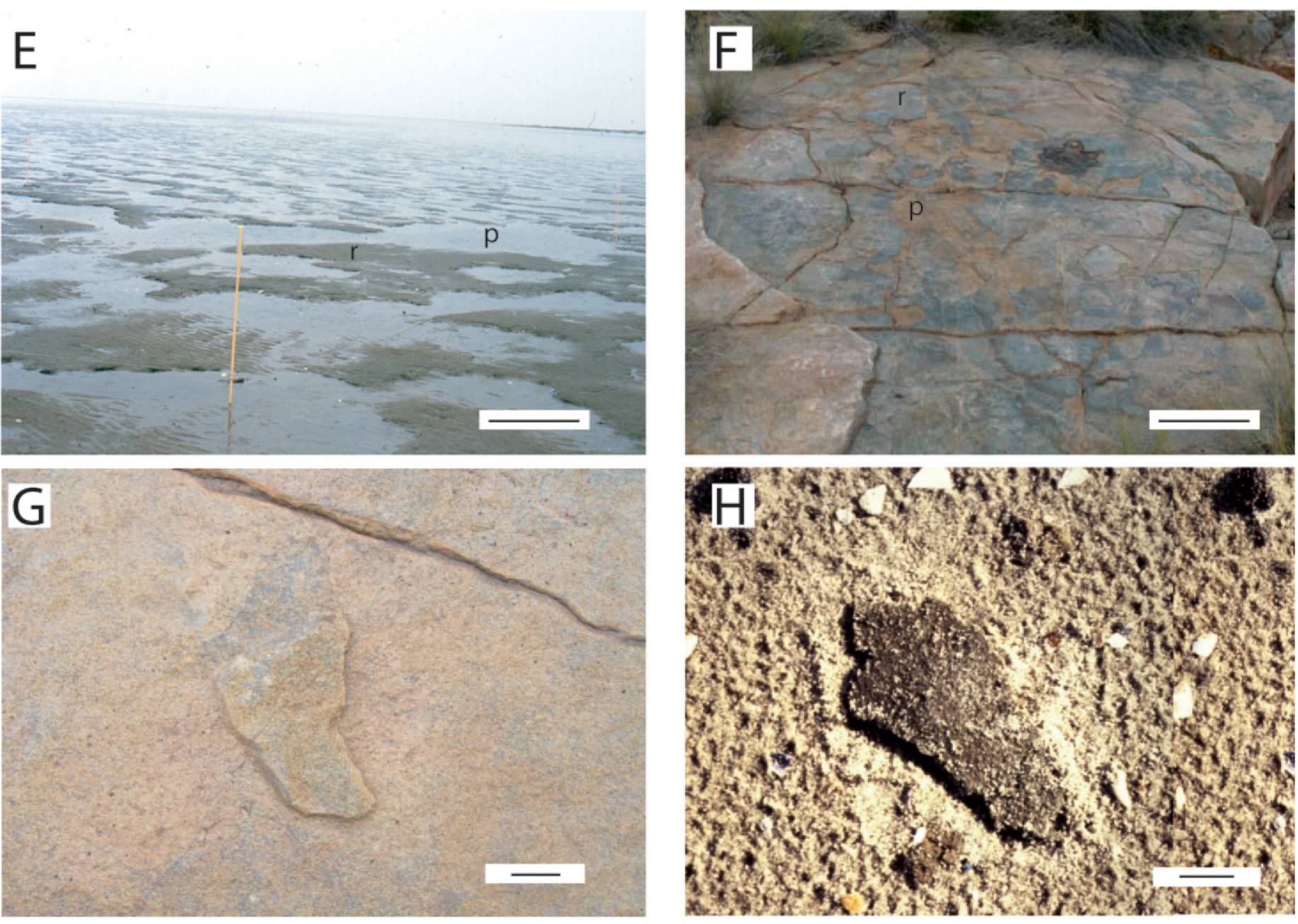


\section{INTERACTION OF BIOFILMS AND MICROBIAL MATS WITH PHYSICAL SEDIMENT DYNAMICS IN SILICICLASTIC DEPOSITS}

Modern sandy tidal flats are widely overgrown by a great variety of benthic microorganisms, especially cyanobacteria. Initially, the microbes form thin, organic coatings around individual sand grains at the sedimentary surface. Such biofilms (Fig. 2A) are composed of cells and extracellular polymeric substances (EPS) (Decho, 1990; Dade et al., 1990). The EPS are adhesive mucilages that enable the benthic microorganisms to attach themselves to solid substrates (such as the surface of a quartz grain), to transport nutrients toward the cell, and to buffer the microbes against the changing salinities in their microhabitat. During times of little water movement, the biofilms continue to grow until an organic layer, composed of a dense and coherent network woven by millions of cyanobacterial trichomes, carpets large areas of the tidal flat surfaces (Fig. 2B) (Stolz, 2000). Other bacteria, fungi, and eukaryotes, such as diatoms, also occur in the mats.

Tidal flats are extreme environments where the twice-daily change from flooding to subaerial exposure provides harsh benthic conditions. However, the mobile trichomes of cyanobacteria are well adapted to quickly changing sedimentary dynamics (e.g., Halfen and Castenholz, 1971; Staley et al., 1989; Gerdes et al., 1991; Golubic and Knoll, 1993; Knoll and Bauld, 1989; Kruschel and Castenholz, 1998; Sumner, 2000).

Interactions of microbenthos with dynamic sedimentary regimes produce MISS. When sediment is deposited onto the mat surface, the filamentous cyanobacteria orientate themselves perpendicularly to the surface and reach into the supernatant sea water. Here they passively comb out suspended grains, a process known as "baffling and trapping" (Black, 1933). Over time, the microbes bind these particles during the formation of their mat fabrics. Binding takes place during quiet hydraulic conditions - a fact that prohibits the formation of microbial mats in strongly and constantly reworked depositional areas. This process can take from a few hours (Oscillatoria limosa, Hardie, 1978; Villbrandt, 1992) to a few weeks (Microcoleus chthonoplastes, Hardie, 1978; Gerdes et al., 1991). Microbial mats protect their sandy substrata against erosion by microbial sediment fixation. Bathurst (1967) and Neumann et al. (1970) described the sediment-stabilizing properties of microbial mats in carbonate sediments of the Bahamas. Subsequently, their field observations were supported by experiments by Meadows et al. (1990), Dade et al. (1990), and Yallop et al., 1994, and the term "biostabilization" was introduced (Paterson, 1997). A microscopic vertical section through a resin-fixed microbial mat shows that the trichomes interweave the sand grains and that the EPS glue the mineral particles together. Both microbial effects significantly increase the resistance of the tidal surface against erosion-the mats can withstand current velocities of up to $1.60 \mathrm{~m} / \mathrm{s}$ (e.g., Führböter and Manzenrieder, 1987).

\section{TYPES OF MISS}

Sixteen types of MISS are generally recognized, the result of growth, biostabilization, binding, baffling, and trapping (Fig. 3). Common examples include the following (see Fig. 1):

- Polygonal oscillation cracks: A polygonal pattern of cracks forms in the microbial mats in hot, semiarid climates characterized by seasonal rainfall in response to periodically changing degrees of moisture (Noffke et al., 2001) (Fig. 1A). The mat polygons defined by the cracks are generally $10-50 \mathrm{~cm}$ in diameter. In vertical section, the mat polygons are thickened; this is caused by lateral oscillation of the mat polygons due to seasonal wet-dry cyclicity. Because the moisture decreases from the lower portions of the organic layer toward the surface, the mat shrivels during desiccation, and the mat polygon margins point upward. With more water, the microbial mat overgrows the desiccation cracks and, viewed from above, two parallel running ridges can be seen, indicating the former presence of up-shriveled polygon margins on the microbial mat surface (Figs. 1A and 1B, arrows). The seasonal repetition of desiccation and remoistening gives rise to polygonal oscillation cracks. In the $2.9 \mathrm{Ga}$ Nhlazatse Section of the Pongola Supergroup, such cracks indicate that Archean paleoclimates there had seasonally high temperatures and variations in precipitation (Fig. 1B; Noffke et al., 2001, 2008).
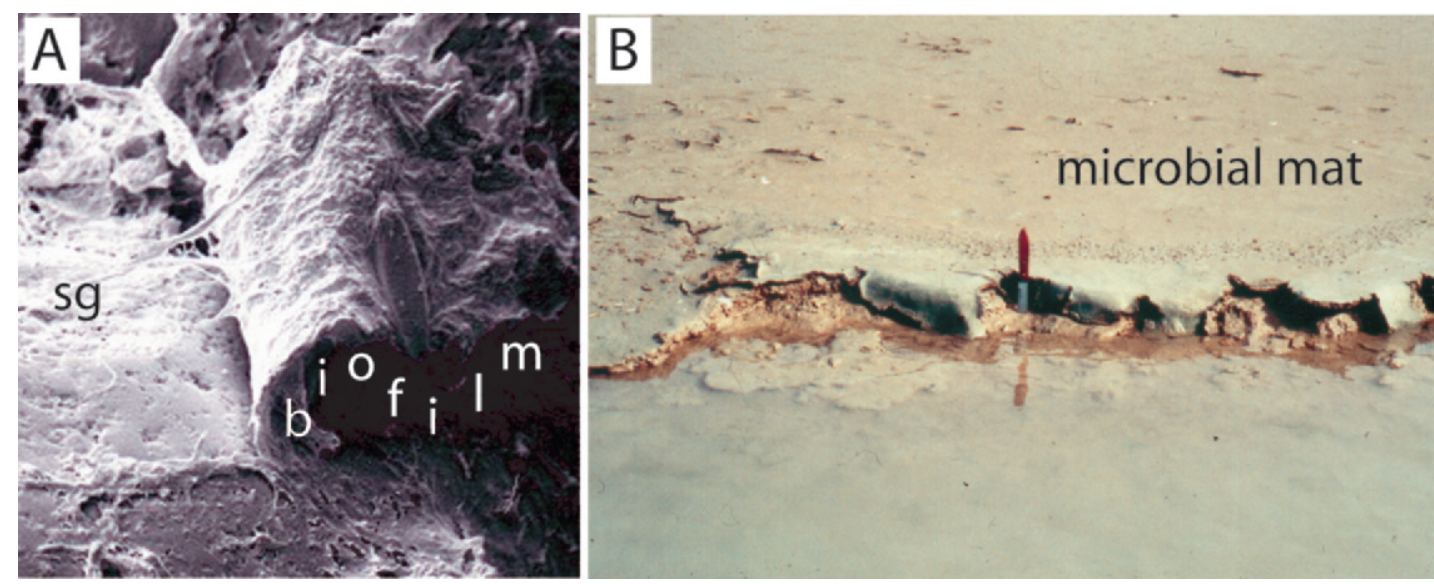

Figure 2. Biofilms and microbial mats. (A) A biofilm is a microscopic, thin organic coating composed of the bacterial mucilages (extracellular polymeric substances) and microbial cells; "sg" indicates the surface of a quartz grain. (B) Microbial mat-a macroscopic, dense and coherent layer that covers a large area of the sedimentary surface. Knife for scale $(10 \mathrm{~cm})$. 


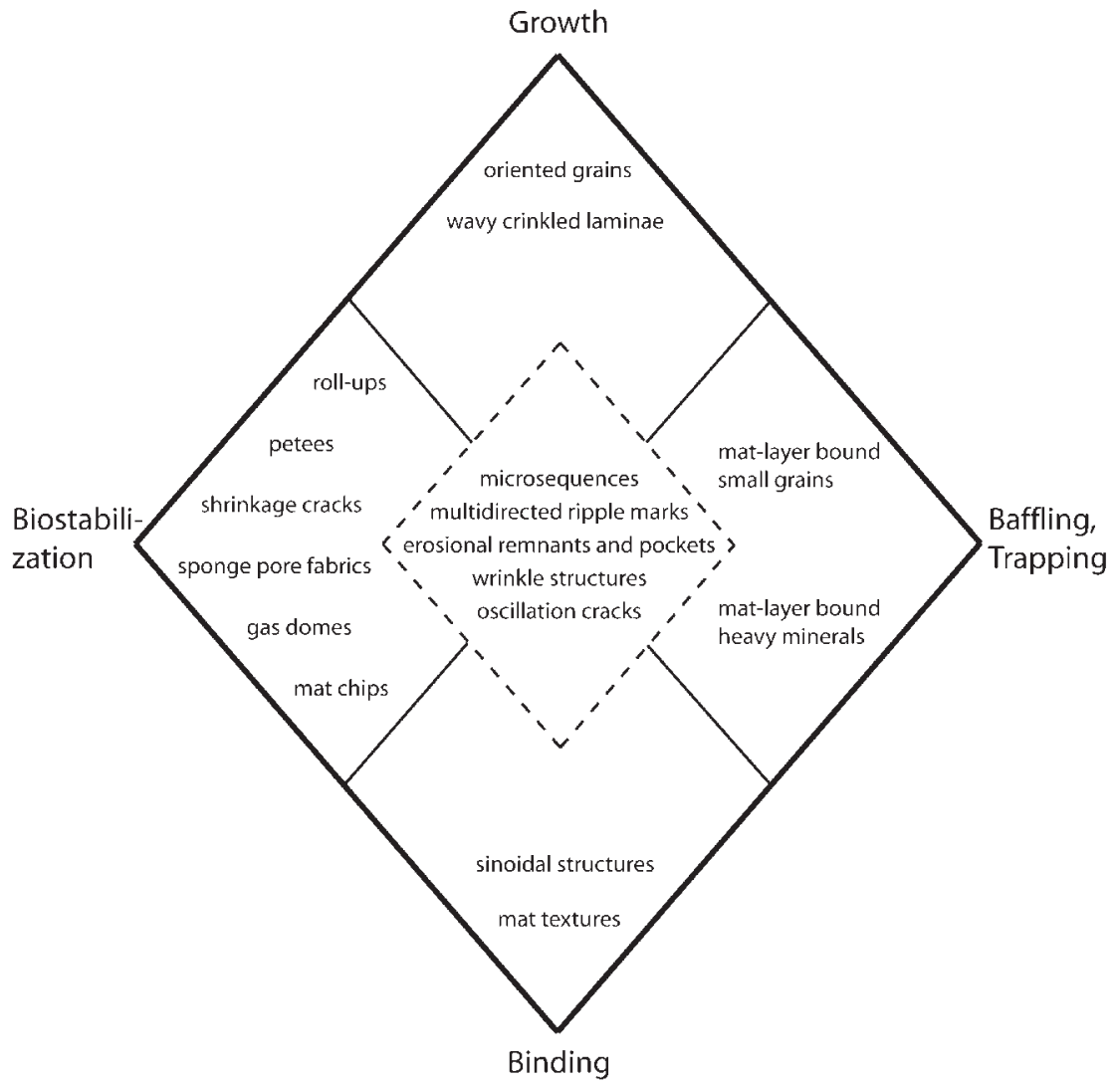

Figure 3. Genetic relationships and classification of microbially induced sedimentary structures (MISS). MISS are formed either by the growth of microbial mats (biomass production), binding (formation of the typical, carpet-like filamentous network), biostabilization (fixation of sedimentary grains), or baffling and trapping (accumulation of sedimentary grains by vertically oriented bacterial filaments). The MISS in the center form from all microbial activities, whereas those structures grouped around it are originated by mainly one microbial behavior (biostabilization, binding, baffling, trapping, or growth).

- Multidirected ripple marks: This is a chaotic pattern of patches of ripple marks of different directions (Figs. $1 \mathrm{C}$ and 1D). Multidirected ripple marks also occur in the supratidal zone and indicate seasonal changes in storm frequencies (Noffke, 1998). During conditions characterized by low hydraulic reworking of the sands, microbial mats start to grow, forming meter-wide patches. The original ripple marks beneath are preserved by biostabilization. On those surface portions still exposed, a storm leaves a new generation of ripple marks in a different direction. After a storm, microbial mat patches continue to enlarge laterally and overgrow those newly rippled surfaces. Another storm produces a third generation of ripple marks in the remaining sand that is not biostabilized. This repetitive alternation between mat growth, biostabilization, and reworking by storms creates the multidirected ripple marks (Noffke, 1998; independently termed by Pflüger [1999] "palimpsest ripple marks"). In the Pongola Supergroup, the multidirected ripple marks (shown in Fig. 1D) reveal a record of four storms and may indicate a storm-dominated coastline (Noffke et al., 2008).

- Erosional remnants and pockets: This surface structure is composed of two morphological elements: elevated surface portions that have flat tops (erosional remnants) and depressions that sometimes are rippled at the bottoms (erosional pockets) (Figs. 1E and 1F; Noffke, 1999). The extent of erosional remnants and pockets varies from at least $30 \mathrm{~cm}$ to many decimeters in scale. Remnants and pockets are caused by the partial erosion of a mat-stabilized sand surface and occur from the lower supratidal zone to the lower intertidal zone. An index derived from the geometries and dimensions of the erosional remnants and pockets quantifies the degrees of growth, biostabilization, and binding, as well as baffling and trapping in the formation of this structure (Noffke and Krumbein, 1999). Today, as well as in the Archean Pongola Supergroup, this index indicates the position of this surface structure on the former lower supratidal flats (Noffke and Krumbein, 1999; Noffke et al., 2008).

- Microbial mat chips: Centimeter-scale pieces of a microbial mat can be ripped off by bottom currents and deposited at a different site (Figs. $1 \mathrm{G}$ and $1 \mathrm{H}$ ). In the fossil record, such scattered mat pieces are one of the most abundant MISS (Pflüger and Gresse, 1996; Noffke et al., 2008). They are predominantly the result of the cohesiveness of microbial mats and therefore purely related to biostabilization.

MISS occur not only as macroscopic structures, but include microscopic textures as well. Microtextures, such as oriented grains (caused by growth) or mat layer-bound grain size populations (caused by baffling and trapping), are indicative of fossil MISS and serve as criteria for their biogenic origin (e.g., Noffke et al., 2003, 2009).

\section{SIGNIFICANCE OF MISS FOR EARTH'S GEOLOGICAL RECORD}

Research on MISS is still in its infancy, and reports on modern and fossil occurrences are likely to increase as the research matures. For now, it is clear that fossil MISS were constructed by mobile and photoautotrophic microbiota. Like today, MISS-forming microbial mats appear to have been distributed 
exclusively in ancient photic zones, and they occur on only moderately reworked fine sand composed of more than $95 \%$ translucent quartz (Noffke et al., 2002). The structures also are clues for the reconstruction of the paleoenvironmental settings. The few examples for MISS listed herein quantify the former current and wave dynamics in ancient settings and suggest the presence of strongly seasonal paleoclimates.

MISS are found in equivalent settings throughout Earth's history, and the recently detected Nhlazatse Section of the Pongola Supergroup shows that neither morphologies nor distributions of MISS have changed for at least 2.9 billion years (Noffke et al., 2008). Given the similarity of today's biota to the 2.9 Ga Archean biotas, it would seem that the early evolution of cyanobacteria involved rapid diversification in perhaps only 200 million years, although their first appearance is uncertain—currently estimated to be 2.7 Ga (Brocks et al., 1999; Knoll, 1999). MISS, by virtue of their ubiquity and high preservation potential, may yet contribute to the answer. The first systematic collection of MISS is deposited in the National Museum of Natural History (Smithsonian Institution) in Washington, D.C., USA.

\section{REFERENCES CITED}

Allwood, A., Walter, M.R., Burch, I.W., and Kamber, B.S., 2007, 3.43 billion-year-old stromatolite reef from the Pilbara Craton of Western Australia: Ecosystem-scale insights to early life on Earth: Precambrian Research, v. 158, p. 198-227, doi: 10.1016/j.precamres.2007.04.013.

Bathurst, G.C., 1967, Oolitic films on low energy carbonate sand grains, Bimini Lagoon, Bahamas: Marine Geology, v. 5, p. 89-109, doi: 10.1016/0025-3227 (67)90073-4.

Black, M., 1933, The algal sediments of Andros Islands, Bahamas: Royal Society of London Philosophical Transactions, Series B, p. 165-192.

Brocks, J.J., Logan, G.A., Buick, R., and Summons, R.E., 1999, Archean molecular fossils and the early rise of eukaryotes: Science, v. 285, p. 1033-1036, doi: 10.1126/science.285.5430.1033.

Buick, R., 1992, The antiquity of oxygenic photosynthesis: evidence from stromatolites in sulfate-deficient Archean lakes: Science, v. 255, p. 74-77, doi: 10.1126/ science. 11536492

Cameron, B., Cameron, D., and Jones, J.R., 1985, Modern algal mats in intertidal and supratidal quartz sands, northeastern Massachusetts, USA, in Curran, A.H., ed., Biogenic structures, their use in interpreting depositional environments: Tulsa, Oklahoma, Society for Sedimentary Geology (SEPM), p. 211-233.

Dade, W.B., Davis, J.D., Nichols, P.D., Nowell, A.R.M., Thistle, D., Trexler, M., and White, D.C., 1990, Effects of bacterial exopolymer adhesion on the entrainment of sand: Geomicrobiology Journal, v. 8, p. 1-16.

Decho, A.W., 1990, Microbial exopolymer secretions in ocean environments: Their role(s) in food webs and marine processes: Oceanographic and Marine Biology Annual Review, v. 28, p. 73-154.

Führböter, A., and Manzenrieder, H., 1987, Biostabilisierung von Sandwatten durch Mikroorganismen, in Gerdes, G., Krumbein, W.E., and Reineck, H.E., eds., Mellum-Portrait einer Insel: Frankfurt, Kramer, p. 123-140.

Furnes, H., Banerjee, N.R., Muehlenbachs, K., Staudigel, H., and de Wit, M.J., 2004, Early Archean life recorded in Archean pillow lavas: Science, v. 304, p. 578-581, doi: $10.1126 /$ science. 1095858.

Gehling, J., 1999, Microbial mats in terminal Proterozoic siliciclastics: Ediacaran death masks, in Hagadorn, J.W., Pflüger, F., and Bottjer, D.J., eds., Unexplored microbial worlds: Palaios, v. 14, p. 40-57.

Gerdes, G., and Krumbein, W.E., 1987, Biolaminated deposits, in Bhattacharya, S., Friedman, G.M., Neugebauer, H.J., and Seilacher, A., eds., Lecture Notes on Earth Sciences, v. 9: Berlin, Springer-Verlag, p. 1-183.

Gerdes, G., Krumbein, W.E., and Reineck, H.E., 1991, Biolaminations-Ecological versus depositional dynamics, in Einsele, G., Ricken, W., and Seilacher, A. eds., Cycles and Events in Stratigraphy: Berlin, Springer-Verlag, p. 592-607.

Gerdes, G., Krumbein, W.E., and Reineck, H.E., 1994, Microbial mats as architects of sedimentary surface structures, in Krumbein, W.E., Paterson, D.M., and Stal, L., eds., Biostabilization of Sediments: Oldenburg, Germany, Bibliotheks und Informations system der Universität Oldenburg, $526 \mathrm{p}$.

Golubic, S.G., and Knoll, A.H., 1993, Prokaryotes, in Lipps, J.H., ed., Fossil prokaryotes and protists: Boston, Blackwell Scientific Publications, p. 51-76.

Grassineau, N.V., Abell, P., Appel, P., Lowry, D., and Nisbet, E.G., 2006, Early life signatures in sulfur and carbon isotopes from Isua, Barberton, Wabigoon, (Steep Rock), and Belingwe greenstone belts (3.8-2.7 Ga), in Kesler, S., and Ohmoto, H., eds., Evolution of early Earth's atmosphere, hydrosphere, and biosphere, constraints from ore deposits: Geological Society of America Memoir 198, p. 33-52.
Grotzinger, J.P., and Knoll, A.H., 1999, Stromatolites in Precambrian carbonates: Evolutionary mileposts or environmental dipsticks?: Annual Review of Earth and Planetary Sciences, v. 27, p. 313-358, doi: 10.1146/annurev.earth.27.1.313.

Hagadorn, J.W., Pflüger, F., and Bottjer, D.J., eds., 1999, Unexplored microbial worlds: Palaios, v. 14, p. 93.

Halfen, L.N., and Castenholz, R.W., 1971, Gliding motility in the blue-green alga, Oscillatoria princeps: Journal of Phycology, v. 7, p. 133-145.

Hardie, L.A., 1978, Sedimentation on the modern tidal flats of northwest Andros Island, Bahamas: Baltimore, Maryland, Johns Hopkins University Press, 202 p.

Hofmann, H.J., Grey, K., Hickman, A.H., and Thorpe, R.I., 1999, Origin of 3.45 Ga coniform stromatolites in the Warawoona Group, Western Australia: Geological Society of America Bulletin, v. 111, p. 1256-1262.

Knoll, A.H., 1999, A new molecular window on early life: Science, v. 285, p. 1025-1026, doi: $10.1126 /$ science.285.5430.1025.

Knoll, A.H., and Bauld, J., 1989, The evolution of ecological tolerance in prokaryotes: Transactions of the Royal Society of Edinburgh, Earth Sciences, v. 80, p. 209-223.

Kruschel, C., and Castenholz, R.W., 1998, The effect of solar UV and visible irradiance on the vertical movements of cyanobacteria in microbial mats: Microbial Ecology, v. 27, p. 53-72, doi: 10.1111/j.1574-6941.1998.tb00525.x.

Lowe, D.R., and Tice, M.M., 2007, Tectonic controls on atmospheric, climatic, and biological evolution 3.5-2.4 Ga: Precambrian Research, v. 158, p. 177-197.

Meadows, P.S., Tait, J., and Hussain, S.A., 1990, Effects of estuarine infauna on sediment stability and particle sediment: Hydrobiology, v. 190, p. 263-266, doi: 10.1007/BF00008194.

Noffke, N., 1998, Multidirected ripple marks rising from biological and sedimentological processes in modern lower supratidal deposits (Mellum Island, southern North Sea): Geology, v. 26, p. 879, doi: 10.1130/0091-7613(1998)026<0879: MRMRFB $>2.3 . C O ; 2$.

Noffke, N., 1999, Erosional remnants and pockets evolving from biotic-physical interactions in a recent lower supratidal environment: Sedimentary Geology, v. 123, p. 175-181, doi: 10.1016/S0037-0738(98)00135-3.

Noffke, N., 2000, Extensive microbial mats and their influences on the erosional and depositional dynamics of a siliciclastic cold water environment (lower Arenigian, Montagne Noire, France): Sedimentary Geology, v. 136, p. 207-215, doi: 10.1016/S0037-0738(00)00098-1.

Noffke, N., 2009, The criteria for the biogeneicity of microbially induced sedimentary structures (MISS) in Archean and younger sandy deposits: Earth Science Review, in press.

Noffke, N., and Krumbein, W.E., 1999, A quantitative approach to sedimentary surface structures contoured by the interplay of microbial colonization and physical dynamics: Sedimentology, v. 46, p. 417-426, doi: 10.1046/j.1365-3091. 1999.00218.x.

Noffke, N., Gerdes, G., Klenke, Th., and Krumbein, W.E., 1996, Microbially induced sedimentary structures-Examples from modern sediments of siliciclastic tidal flats: Zentralblatt für Geologie und Paläontologie, Teil I, 1995, p. 307-316.

Noffke, N., Gerdes, G., Klenke, Th., and Krumbein, W.E., 2001, Microbially induced sedimentary structures indicating climatological, hydrological and depositional conditions within Recent and Pleistocene coastal facies zones (southern Tunisia): Facies, v. 44, p. 23-30, doi: 10.1007/BF02668164.

Noffke, N., Knoll, A.H., and Grotzinger, J., 2002, Sedimentary controls on the formation and preservation of microbial mats in siliciclastic deposits: A case study from the upper Neoproterozoic Nama Group, Namibia: Palaios, v. 17, p. 533-544, doi: 10.1669/0883-1351(2002)017<0533:SCOTFA >2.0.CO;2.

Noffke, N., Hazen, R., and Nhleko, N., 2003, Earth's earliest microbial mats in a siliciclastic marine environment (Mozaan Group, $2.9 \mathrm{Ga}$, South Africa): Geology, v. 31, p. 673-676, doi: 10.1130/G19704.1.

Noffke, N., Hazen, R.M., Eriksson, K., and Simpson, E., 2006, A new window into early life: Microbial mats in a siliciclastic early Archean tidal flat (3.2 Ga Moodies Group, South Africa): Geology, v. 34, p. 253-256, doi: 10.1130/G22246.1.

Noffke, N., Beukes, N., Bower, D., Hazen, R.M., and Swift, D., 2008, An actualistic perspective into Archean worlds_-(cyano-) bacterially induced sedimentary structures in the siliciclastic Nhlazatse Section, 2.9 Ga Pongola Supergroup, South Africa: Geobiology, v. 6, p. 5-20.

Neumann, A.C., Gebelein, C.D., and Scoffin, T.P., 1970, The composition, structure and erodibility of subtidal mats, Abaco, Bahamas: Journal of Sedimentary Petrology, v. 40, p. 274-297.

Paterson, D.M., 1997, Biological mediation of sediment erodibility: Ecology and physical dynamics, in Burt, N., Parker, R., and Watts, J., eds., Cohesive Sediments: London, John Wiley and Sons, p. 215-229.

Pflüger, F., 1999, Matground structures and redox facies, in Hagadorn, J.W., Pflüger, F., and Bottjer, D., eds., Unexplored microbial worlds: Palaios, v. 14, p. 25-39.

Pflüger, F., and Gresse, P.G., 1996, Microbial sand chips: a non-actualistic sedimentary structure: Sedimentary Geology, v. 102, p. 263-274, doi: 10.1016/0037-0738 (95)00072-0.

Runnegar, B.N., and Fedonkin, M.A., 1992, Proterozoic metazoan body fossils, in Schopf, J.W., and Klein, C., eds., The Proterozoic Biosphere, a Multidisciplinary Study: New York, Cambridge University Press, p. 369-387.

Schieber, J., 1998, Possible indicators of microbial mat deposits in shales and sandstones: Examples from the Mid-Proterozoic Belt Supergroup, Montana, USA: Sedimentary Geology, v. 120, p. 105-124, doi: 10.1016/S0037-0738(98)00029-3.

Schieber, J., Banerjee, S., Bose, P.K., Eriksson, P.G., Sarkar, S., Altermann, W., and Catuneau, O., 2007, Atlas of Microbial Mat Features Preserved in the Siliciclastic Rock Record: Amsterdam, Elsevier, 335 p. 
Schopf, J.W., Kudryavtsev, A.B., Czaja, A.D., and Trupathi, A.B., 2007, Evidence of Archean life: Stromatolites and microfossils: Precambrian Research, v. 158 p. 141-155, doi: 10.1016/j.precamres.2007.04.009

Seilacher, A., Reif, W.E., and Westphal, F., 1985, Sedimentological, ecological, and temporal patterns of fossil Lagerstätten: Royal Society of London Philosophical Transactions, ser. B, v. 311, p. 5-23.

Staley, J.T., Bryant, M.P., Pfennig, N., and Holt, J.G., 1989, Bergey's manual of systematic biology: Baltimore, Williams \& Wilkins, $2648 \mathrm{p}$.

Stolz, J.F., 2000, Structure of microbial mats and biofilms, in Riding, R., and Awramik, S.M., eds., Microbial Sediments: Berlin, Springer-Verlag, p. 1-8.

Sumner, D.Y., 2000, Microbial vs. environmental influences on the morphology of Late Archean fenestrate microbialites, in Riding, R., and Awramik, S.M., eds., Microbial Sediments: Heidelberg, Springer-Verlag, p. 307-314.
Villbrandt, M., 1992, Interactions of nitrogen fixation and photosynthesis in marine cyanobacterial mats (Mellum, North Sea) [Ph.D. Thesis]: Oldenburg, Bibliotheks Informations System, University of Oldenburg, 229 p.

Yallop, M.L., De Winder, B., Paterson, D.M., and Stal, L.J., 1994, Comparative study on primary production and biogenic stabilization of cohesive and non-cohesive marine sediments inhabited by microphytobenthos: Estuarine, Coastal and Shelf Science, v. 39, p. 565-582, doi: 10.1016/S0272-7714(06)80010-7.

\section{GSA ANNUAL MEETING \& EXPOSITION}

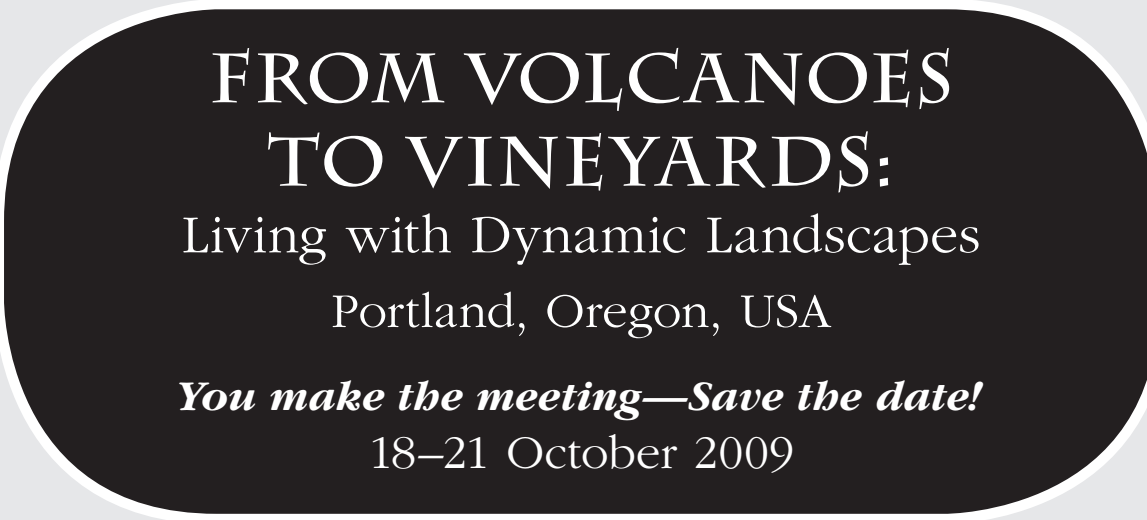

\section{Call for Proposals}

Technical Sessions

Submit technical sessions proposals at http://gsa.confex.com/gsa/2009AM/ sessionproposals.epl.

\section{Field Trips}

Know of a great geoscience excursion near Portland? Teach your colleagues and peers about the ground-breaking research in this region. Trips can be anywhere from a half day to five days long.

Submit your idea for a fun, interesting, and educational field trip for the 2009 Annual Meeting online at http://gsa.confex.com/gsa/2009AM/fieldtrip.htm. Questions? Please contact Eric Nocerino, +1-303-357-1060, enocerino@geosociety.org.

\section{Short Courses}

Have something that your peers, students, or earth science teachers need to know? Share your unique knowledge and experience in our dynamic annual meeting setting.

Learn how to submit your short course proposal at www.geosociety.org/ meetings/2009/scProposals/. Questions? Please contact Jennifer Nocerino, +1-303357-1036, jnocerino@geosociety.org.

Please submit your proposals by 2 December 2008.

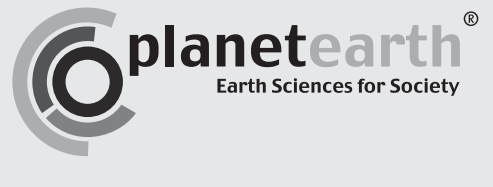

THE GEOLOGICAL SOCIETY OF AMERICA ${ }^{\circledR}$

SCIENCE - STEWARDSHIP - SERVICE

\section{Field Geology} ILLUSTRATED Terry S. Maley

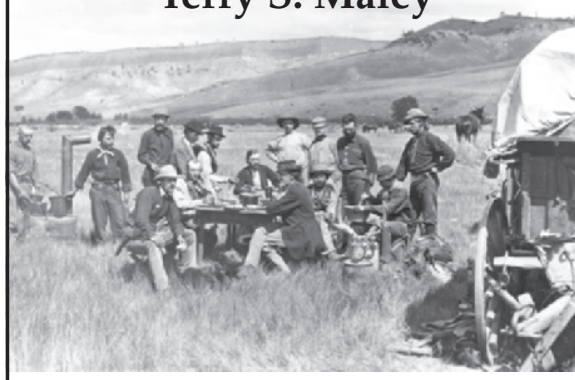

First detailed, comprehensive book on field geology in 20 years.

704-page, richly illustrated book with 688 high quality photographs and 300 interpretive sketches; a treasure trove of practical field-related information essential for the recognition, interpretation, and description of geologic features.

This superb field guide includes hundreds of classic USGS photographs and represents some of the best examples available of common and significant geologic features and structures.

\section{2nd edition, 2005, \$35.00 plus \$4 shipping}

Mineral Land Publications, P.0. Box 1186,

Boise, Idaho 83701 Phone: 208-343-9143

\section{Call for Papers:} GSA Today

Submit your hot-topic science or Groundwork article online.

Follow the links at www.geosociety.org/pubs/. GSA Today articles boast a rapid turnaround from acceptance

to publication (2007 avg. = 93.7 days). 